\title{
Studies of lipopolysaccharide effects on the induction of a-synuclein pathology by exogenous fibrils in transgenic mice
}

\author{
Nicola J. Rutherford, Amanda N. Sacino, Mieu Brooks, Carolina Ceballos-Diaz, Thomas B. Ladd, Jasie K. Howard, \\ Todd E. Golde and Benoit I. Giasson*
}

\begin{abstract}
Background: Parkinson's disease (PD) is a progressive neurodegenerative disorder that is pathologically characterized by loss of dopaminergic neurons from the substantia nigra, the presence of aggregated a-synuclein (aS) and evidence of neuroinflammation. Experimental studies have shown that the cerebral injection of recombinant fibrillar aS, especially in aS transgenic mouse models, can induce the formation and spread of aS inclusion pathology. However, studies reporting this phenomenon did not consider the presence of lipopolysaccharide (LPS) in the injected aS, produced in E. coli, as a potential confound. The objectives of this study are to develop a method to remove the LPS contamination and investigate the differences in pathologies induced by aS containing LPS or aS highly purified of LPS.
\end{abstract}

Results and conclusions: We were able to remove $>99.5 \%$ of the LPS contamination from the aS preparations through the addition of a cation exchange step during purification. The aS pathology induced by injection of fibrils produced from aS containing LPS or purified of LPS, showed a similar distribution pattern; however, there was less spread into the cortex of the mice injected with aS containing higher levels of LPS. As previously reported, injection of aS fibrils could induce astrogliosis, and aS inclusions were present within astrocytes in mice injected with fibrils comprised of as with or without cation exchange purification. Furthermore, we identified the presence of aS pathology in ependymal cells in both groups of mice, which suggests the involvement of a novel mechanism for spread in this model of aS pathology.

Keywords: Lipopolysaccharide, a-synuclein pathology, Transgenic mice, Neuroinflammation, Parkinson's disease

\section{Background}

Parkinson's disease (PD) is characterized by the profound loss of nigral dopaminergic neurons, the presence of proteinacious inclusions comprised of aggregated $\alpha-$ synuclein $(\alpha S)$ in some of the remaining neurons, and neuroinflammation in affected brain regions [1-4]. PD is related to several other neurodegenerative diseases, including dementia with Lewy bodies (DLB), due to the presence of pathological $\alpha S$ inclusions [5-7]. Studies of human pathology have supported the notion that $\alpha \mathrm{S}$ aggregation may spread along neuroanatomical pathways associated with disease progression $[8,9]$.

\footnotetext{
*Correspondence: bgiasson@ufl.edu

Center for Translational Research in Neurodegenerative Disease, Department of Neuroscience, University of Florida, 1275 Center Drive, Room BMS J-483, PO Box 100159, Gainesville, FL 32610, USA
}

It is believed that one method involved in the spread of $\alpha \mathrm{S}$ pathology associated with disease progression is cell-to-cell transmission of aggregated $\alpha \mathrm{S}$ seeds followed by prion-like conformational templating. This notion has been supported by the presence of $\alpha \mathrm{S}$ inclusions within fetal dopaminergic neuronal transplants in the brains of PD patients [10-12]. Experimental mouse studies using recombinant fibrillar $\alpha \mathrm{S}$, produced in bacteria, to induce the spread of $\alpha \mathrm{S}$ pathology throughout the neuroaxis of $\alpha \mathrm{S}$ transgenic ( $\mathrm{Tg}$ ) and non-Tg mice have further suggested that $\alpha \mathrm{S}$ aggregation may be able to spread by "prion-like" conformational templating mechanisms [13-18]. However, most of these studies did not take into account that the possible presence of bacterial endotoxin/lipopolysaccharide (LPS) may confound some of these results. The importance of this issue is 
underscored by reports that the intracerebral or peripheral administration of LPS alone to mice $\mathrm{Tg}$ for $\alpha \mathrm{S}$ containing the PD-causing A53T mutation (M83 line), which were used to show cerebral spread of $\alpha \mathrm{S}$ inclusion pathology using bacterial recombinant $\alpha S$ aggregates $[13,16]$, can induce $\mathrm{CNS} \alpha \mathrm{S}$ inclusion pathology $[19,20]$. LPS is a major component of the E. coli bacterial cell wall and is a potent inducer of inflammation, by activating the toll-like receptor 4 (TLR4) [21, 22], nevertheless, endogenous $\alpha \mathrm{S}$ itself can reportedly trigger an immune response through a similar mechanism [23-27].

Activation of the innate neural immune response is a consistent finding associated with PD and it is believed to contribute to disease pathogenesis [3, 28, 29], however it is unknown whether this process is responsible for the onset of disease, it's progression and/or if it exacerbates existing neurodegeneration. Neuroinflammation is evidenced by the presence of astrogliosis, activated microglia (the immune cells of the CNS) and increased levels of proinflammatory cytokines [30-32]. Furthermore, it is believed that a chronic brain inflammatory state can be damaging, as factors produced and released during such a state can cause/add to oxidative stress [32].

In this study we show that $\alpha \mathrm{S}$ purified from E. coli consistently contains LPS that is difficult to completely remove, likely due the lipid binding and ionic properties of $\alpha \mathrm{S}$ [33]. Nevertheless, performing stereotaxic brain injections with preformed fibrils comprised of $\alpha S$ highly purified of LPS compared to $\alpha S$ with co-purified LPS in $\alpha \mathrm{S} \mathrm{Tg}$ mice, we demonstrate similar induction and spread of $\alpha \mathrm{S}$ throughout the neuroaxis. Additionally, we show that the removal of LPS from the injected $\alpha \mathrm{S}$ does not affect the number of GFAP-reactive astrocytes present in the hippocampus or entorhinal cortex, and $\alpha \mathrm{S}$ inclusions are present in astrocytes in both injection groups. Interestingly, during the course of these studies, we observed that in this induced model of $\alpha \mathrm{S}$ inclusion pathology there is not only significant induction of aggregates in neurons and glia, but also in ependymal cells. This expands the number of cell types that can contain $\alpha \mathrm{S}$ pathology and could have important implications for the mechanism involved in the spread of $\alpha \mathrm{S}$ inclusion pathology.

\section{Results}

\section{Quantification of endotoxin/LPS contamination in standard aS protein preparations}

$\alpha S$ protein was expressed in and purified from $E$. coli, which natively contains endotoxins, i.e. LPS. LPS is an abundant molecule within the membrane of Gram-negative bacteria, and is a notorious contaminant of protein purified from E. coli $[34,35]$. LPS is a potent activator of the immune response; injection of just $4 \mathrm{ng} / \mathrm{kg}$ body weight (approximately $40 \mathrm{EU} / \mathrm{kg}$ ) can cause a dramatic increase in inflammatory markers in humans [36]. The United States Pharmacopeia (USP) recommends that vaccines/injectable medications contain $<5 \mathrm{EU} / \mathrm{kg}$ body weight [37]. It is also well known that it is difficult to completely remove LPS from bacterial protein preparations due to its ionic and hydrophobic properties, and the formation of a spectrum of multimeric complexes with varied size properties [34, 38, 39]. As $\alpha \mathrm{S}$ is a lipid binding protein [33] and it has hydrophobic, negatively charged and positively charged domains (Fig. 1a), we wanted to assess the extent to which our standard bacterial protein preparations may be contaminated with LPS. We employed the standard LAL in vitro method and a TLR4 cell responder assay to determine the levels of endotoxin contamination, using purified endotoxin as our standard (Fig. 1b and c). We found that our bacterial $\alpha \mathrm{S}$ protein preparations contained varying levels of LPS, as shown for one preparation in Fig. 1. The TLR4 assay indicates that there are $>50 \mathrm{EU} / \mathrm{ml}$ in $0.1 \mu \mathrm{M}$ protein sample (i.e. $>34.6 \mathrm{EU} / \mu \mathrm{g} \alpha \mathrm{S}$ protein). Trying different methods, we found that it was difficult to remove the LPS from our preparations, but by lowering the $\mathrm{pH}$ to 4.2 and using cation affinity purification with extensive washing, we were able to remove $>99.5 \%$ of the bacterial endotoxin contamination from our recombinant $\alpha \mathrm{S}$ protein samples, although some residual amounts $(<0.5 \mathrm{EU} / \mathrm{ml}$ in $1 \mu \mathrm{M}$ protein sample; $<0.035 \mathrm{EU} / \mu \mathrm{g} \alpha \mathrm{S}$ protein) were still detected with the more-sensitive LAL assay (Fig. 1c). Samples from these same preparations of recombinant human $\alpha \mathrm{S}$ prior to cation exchange purification $(\alpha S)$ or after purification (cation exchanged $\alpha S$ ) were fibrillized, sonicated and used for stereotaxic injection into $\alpha \mathrm{S} \mathrm{Tg}$ mice. Following surgery, the LAL assay was repeated on the remaining $\alpha \mathrm{S}$ fibrils. We found that although the amount of endotoxin within the cation exchanged $\alpha \mathrm{S}$ fibrils increased $(\sim 5 \mathrm{EU} / \mathrm{ml}$ in $1 \mu \mathrm{M}$ protein sample; $\sim 0.35 \mathrm{EU} /$ $\mu \mathrm{g} \quad \alpha \mathrm{S}$ protein), there was $\geq 99 \%$ less endotoxin present in these $\alpha \mathrm{S}$ fibrils than in the non-cation exchanged $\alpha S$ fibrils.

\section{Effects of endotoxin contamination on the induction and spread of aS pathology in M83 aS Tg mice}

M83 $\alpha \mathrm{S}$ Tg mice express human A53T $\alpha \mathrm{S}$ driven by the mouse prion-protein promoter. These mice develop an age-dependent motor phenotype resulting in paralysis that is associated with the formation of $\alpha \mathrm{S}$ inclusions in the spinal cord, brain stem and midbrain [40]. These pathological changes can occur between 7 


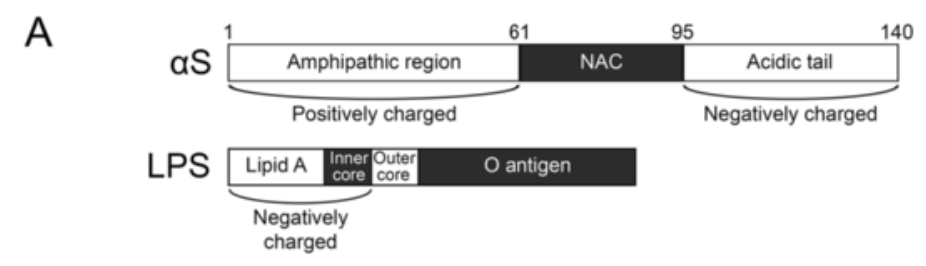

B

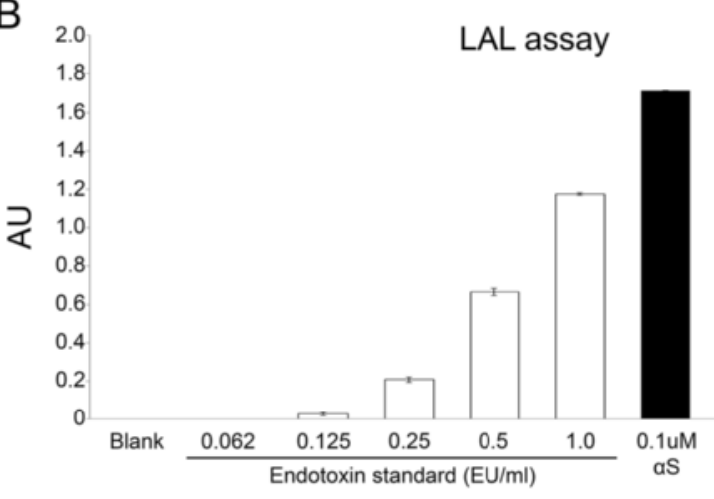

LAL assay

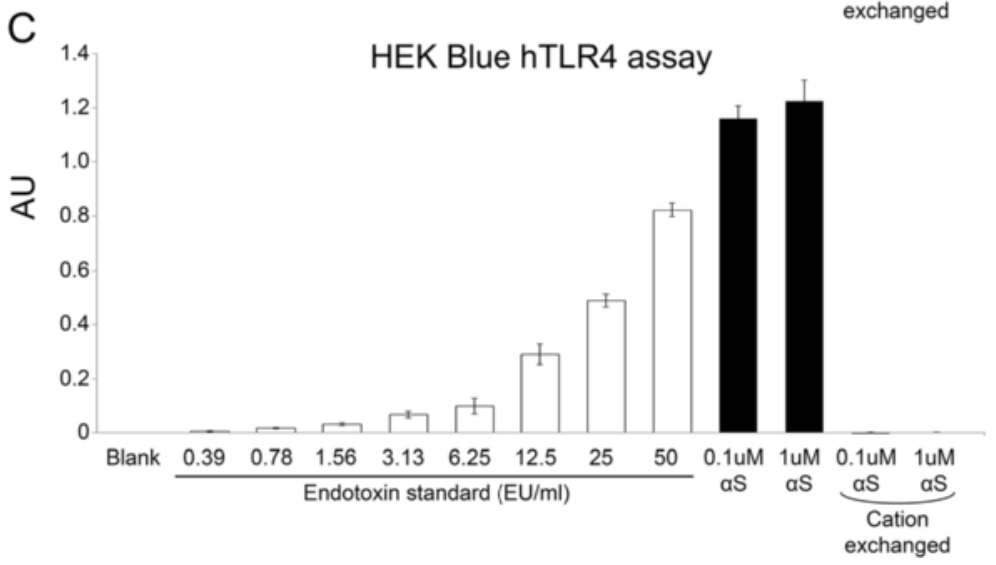

Fig. 1 Assessment of endotoxin/LPS contamination in aS protein preparations. a Schematics showing the charged regions and hydrophobic regions of aS and LPS. NAC = "non-amyloid- $\beta$ component of the amyloid plaque" hydrophobic region of aS. (b and $\mathbf{c}$ ) Average quantification of endotoxin contaminants in aS protein preparations. Results are also shown for samples that were further purified using High S resin (cation exchanged). (b) and (c) illustrate contamination in the same sample set, using the Pierce LAL assay and the InvivoGen HEK-Blue-hTLR4 cell culture system respectively. The hTLR4 assay shows an expanded standard curve. $1 \mu \mathrm{M}$ aS $=0.0146 \mathrm{mg} / \mathrm{ml}$. White bars represent the endotoxin standard and black bars represent test samples. Error bars represent the standard error of the mean. $A U=$ absorbance units

and 16 months of age in homozygous M83 $\alpha \mathrm{S} \mathrm{Tg}$ mice, but later than 22 months of age in hemizygous mice [40]. Intracerebral injections of preformed $\alpha S$ amyloid fibrils, generated from recombinant $\alpha \mathrm{S}$ produced in E. coli, have been shown to induce the formation of $\alpha \mathrm{S}$ inclusion pathology that spreads from the site of injection $[13,15,16]$. However, levels of LPS contamination were not taken into consideration in these studies, and it was previously reported that both peripheral or brain injection of LPS can induce $\alpha S$ inclusion pathology in M83 $\alpha \mathrm{S} \operatorname{Tg}$ mice $[19,20]$. Given that we were able to generate recombinant $\alpha \mathrm{S}$ that is largely devoid of LPS, we tested whether LPS contamination significantly altered the induction of brain $\alpha S$ inclusion pathology following intracerebral injection of preformed amyloid fibrils. Fibrils produced from $\alpha S$ and cation exchanged $\alpha \mathrm{S}$ were stereotaxically injected into the hippocampus of 2 month old hemizygous M83 $\alpha \mathrm{S} \mathrm{Tg}$ mice. Immunohistochemical analysis of the brains and spinal cords of these mice (Fig. 2a) revealed the presence of inclusions that were immunoreactive for antibodies to $\alpha \mathrm{S}$ (Syn506), Ser129 phosphorylated $\alpha \mathrm{S}$ (pSer129/81A) and a general inclusion marker (p62) in mice injected with fibrils produced from $\alpha S$ or cation exchanged $\alpha S$. Formation of authentic $\alpha \mathrm{S}$ inclusion pathology was also confirmed by double-immunofluorescence microscopy with antibodies to $\alpha \mathrm{S}$ (SNL4) and Ser129 phosphorylated $\alpha \mathrm{S}$ (pSer129/81A; Fig. 3). Distribution analysis of the $\alpha \mathrm{S}$ 


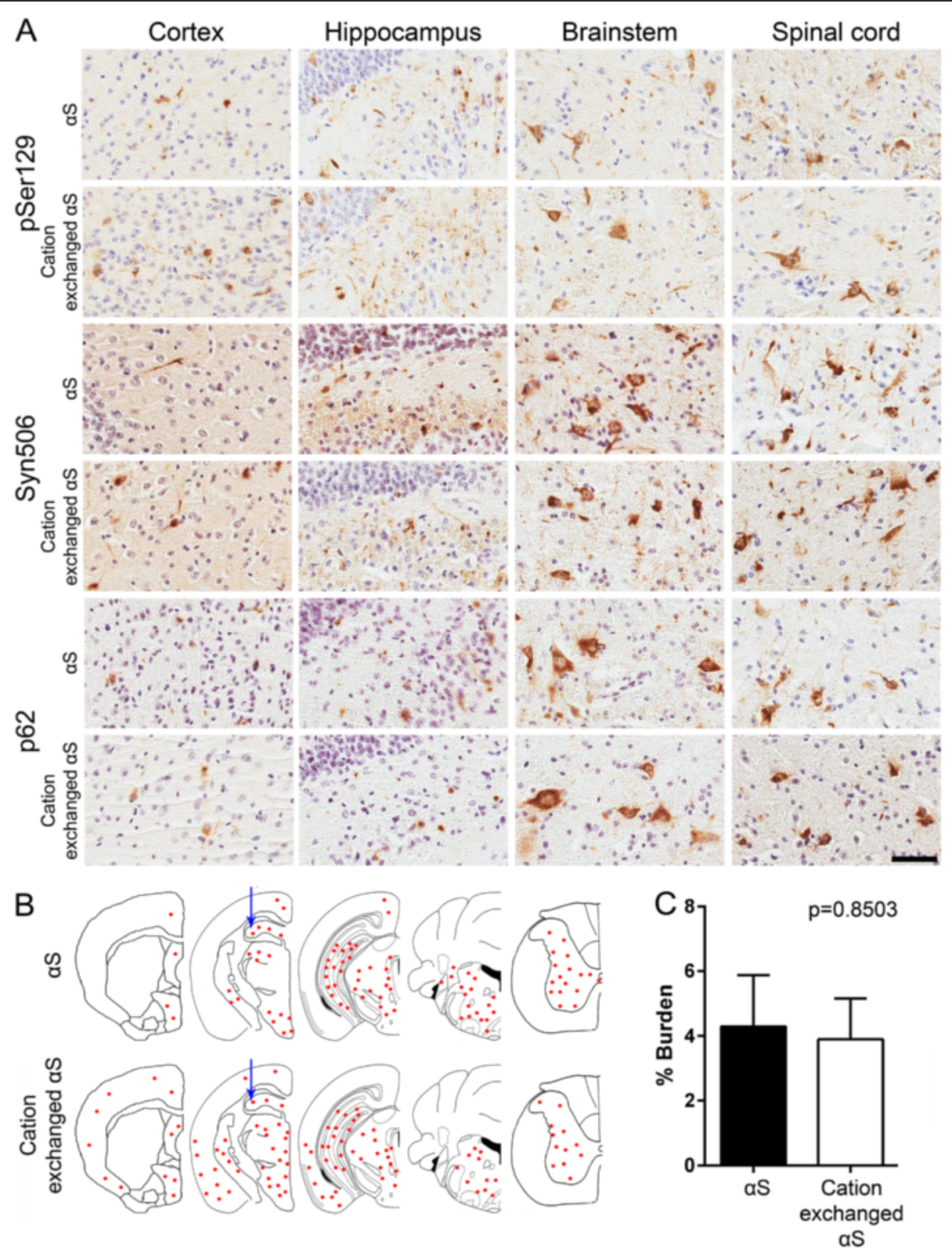

Fig. 2 aS pathology in M83 aS Tg mice following injection of aS or cation exchanged aS fibrils. a Representative immunohistochemical images of cortical, hippocampal, brainstem, and spinal cord sections of hemizygous M83 aS Tg mice stereotaxically injected in the hippocampus with aS or LPS purified (cation exchanged) aS. Antibodies to aS (Syn506), to aS phosphorylated at Ser129 (pSer129/81A), and a general inclusion marker (p62) were used. Scale bar $=50 \mu \mathrm{m}$. $\mathbf{b}$ Schematic representation of the distribution of aS inclusion pathology in the neuroaxis of hemizygous M83 aS Tg mice injected with aS or cation exchanged aS fibrils. Red dots indicate the sites and amounts of aS pathology. Blue arrows indicate the site of injection. c Quantification of Syn506 staining in the hippocampus of mice injected with aS or cation exchanged aS fibrils. The p-value was calculated using a two-tailed $t$-test. Error bars represent the standard error of the mean

pathology (Fig. 2b) showed a high concentration of inclusions at the site of injection in both sets of mice and quantification of Syn506 staining in this region revealed no difference between the two groups (Fig. 2c). Pathology was observed to have spread caudally, to the brainstem and spinal cord in both groups, with similar frequencies of inclusions. The only major difference detected between the distributions of inclusions in the two groups was the spread of $\alpha \mathrm{S}$ pathology into the cortex of the mice. In mice injected with cation exchanged $\alpha \mathrm{S}$, inclusions appeared with moderate frequency throughout the cortex, whereas cortical inclusions in the $\alpha \mathrm{S}$ injected mice were rare, and only observed in dorsal regions.

To further assess the involvement of LPS contamination in driving the formation of $\alpha S$ pathology, we stereotaxically injected homozygous M83 $\alpha \mathrm{S}$ Tg mice 


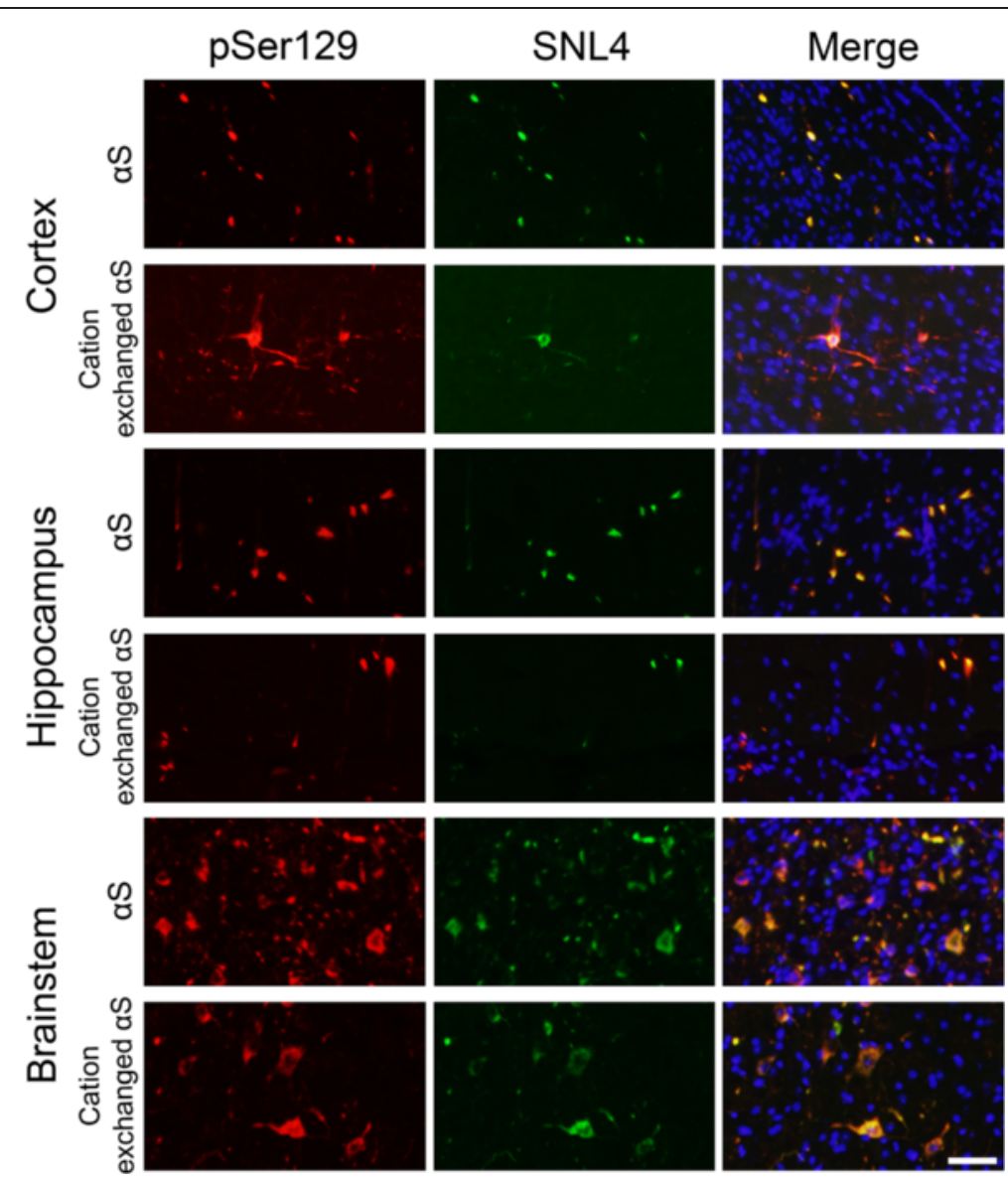

Fig. 3 Immunofluorescence analysis of aS pathology in M83 aS Tg mice following injection of aS fibrils. Representative immunofluorescent images of the cortical, hippocampal, and brainstem regions of hemizygous M83 aS Tg mice injected with aS or cation exchanged aS fibrils, stained with antibodies to phosphorylated aS (pSer129/81A; red) or aS (SNL4; green) and DAPI (blue). Individual images were overlaid to show colocalization (Merge). Scale bar $=50 \mu \mathrm{m}$

in the hippocampus with $10 \mu \mathrm{g}$ of purified LPS, with an activity of $\sim 0.25 \mathrm{EU} / \mathrm{pg}$ (Additional file 1: Figure S1A). This constitutes greater than 10 million fold more endotoxin units than were present in the cation exchanged $\alpha \mathrm{S}$ used for injection. We used homozygous mice as they should be more primed for the induction of pathology, but in these studies no $\alpha \mathrm{S}$ inclusion pathology was observed (Fig. 4). Similarly, injection of PBS into the hippocampus of homozygous M83 $\alpha \mathrm{S}$ Tg mice did not induce the formation of $\alpha \mathrm{S}$ inclusion pathology (data not shown) indicating that it is the injected $\alpha S$ fibrils that are responsible for the induction of $\alpha S$ inclusions. We confirmed that the purified LPS was able to induce an inflammatory response, by treating primary microglial cultures produced from $\mathrm{nTg}$ mice with the same LPS that was injected. As expected, we observed changes in morphology of the cells over time; they became round and swollen with vacuoles evident after $12 \mathrm{~h}$ of treatment with LPS (Additional file 1: Figure S1B).
We also detected a concomitant rise in protein levels of interleukin-6 (IL-6), a marker of inflammation, within the media of the LPS treated cells after $6 \mathrm{~h}$ of treatment, which increased to $19.6 \mathrm{ng} / \mathrm{ml}$ compared to media from control cells, which remained below the level of detection (Additional file 1: Figure S1C).

\section{Astrocyte activation and induction of astrocytic aS} inclusion pathology due to hippocampal injection of recombinant of aS fibrils

We recently reported that the hippocampal injection of fibrillar $\alpha \mathrm{S}$ in M83 $\alpha \mathrm{S}$ Tg mice also resulted in the induction of astrogliosis and that a significant proportion of induced $\alpha \mathrm{S}$ inclusion pathology was actually in glial cells [41]. To assess if the changes in glia were due to the presence of LPS in the fibrillar $\alpha S$ that was injected, we assessed the abundance of astrogliosis, by staining for GFAP, in the brains of M83 $\alpha \mathrm{S} \mathrm{Tg}$ mice that were injected with $\alpha \mathrm{S}$, cation exchanged $\alpha \mathrm{S}$, LPS or PBS. In this cohort of mice, the density of 


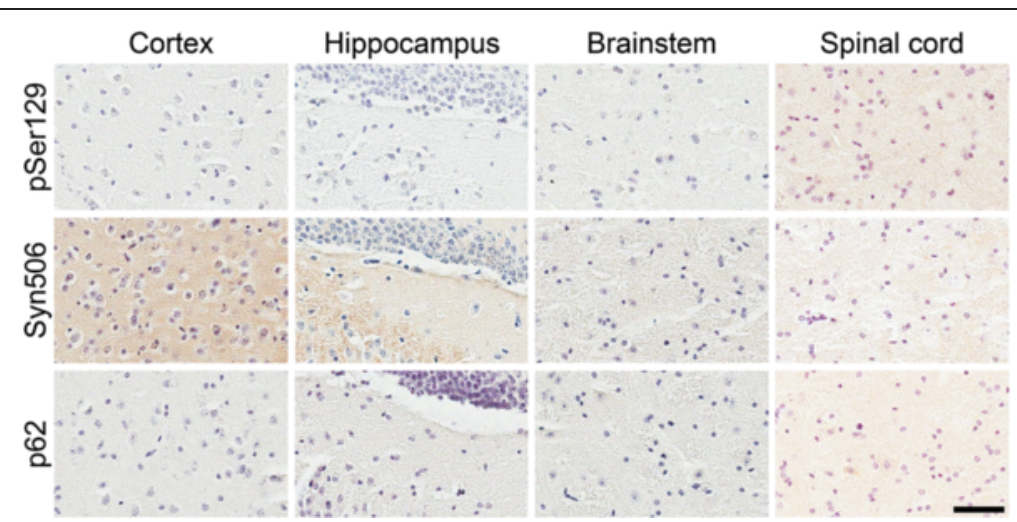

Fig. 4 Immunohistochemical analysis showing the paucity of aS pathology in M83 aS Tg mice injected with LPS. Representative immunohistochemical images from the cortex, hippocampus, brainstem, and spinal cord of homozygous M83 aS Tg mice injected with LPS, using antibodies to aS (Syn506), to aS phosphorylated at Ser129 (pSer129/81A), and a general inclusion marker (p62). No immunoreactive inclusions were identified in these mice. Scale bar $=50 \mu \mathrm{m}$

GFAP-positive astrocytes in the hippocampus and entorhinal cortex was elevated in $\alpha \mathrm{S}$ and LPS injected mice compared to PBS controls, but did not reach statistical significance (Fig. 5a). We also assessed whether there was similar induction of $\alpha \mathrm{S}$ inclusion pathology in glial cells and found that $\alpha \mathrm{S}$ inclusions were present in astrocytes in both $\alpha \mathrm{S}$ and cation exchanged $\alpha \mathrm{S}$ injected mice (Fig. 5b).

\section{Induction of ependymal aS inclusion pathology resulting from the hippocampal injection of recombinant aS fibrils} Expending the observations of $\alpha \mathrm{S}$ inclusion pathology in glia, we also observed a similar induction of $\alpha \mathrm{S}$ inclusions in ependymal cells of M83 $\alpha \mathrm{S} \mathrm{Tg}$ mice injected in the hippocampus with preformed $\alpha \mathrm{S}$ fibrils (Fig. 6a and b). In comparison, $\alpha \mathrm{S}$ inclusion pathology within ependymal cells was not observed in naïve M83 $\alpha \mathrm{S}$ Tg mice that become motor impaired and develop $\alpha S$ inclusions due to aging (Fig. 6d). To assess if the formation of ependymal $\alpha \mathrm{S}$ pathology in $\alpha \mathrm{S}$ injected M83 $\alpha \mathrm{S}$ Tg mice was unique to this mouse line, we re-examined the pathology in M20 $\alpha \mathrm{S}$ Tg mice that were also challenged with hippocampal injection of fibrillar $\alpha \mathrm{S}$ (Fig. 7a). We found that ependymal $\alpha \mathrm{S}$ inclusion pathology was also present in these mice, albeit less abundant than in M83 $\alpha \mathrm{S}$ Tg mice. We did not detect any ependymal cell $\alpha S$ pathology in either mouse line injected with PBS (Figs. 6c and 7b). Furthermore, injection of $\alpha \mathrm{S}$ fibrils into non-Tg mice did not induce the formation of $\alpha \mathrm{S}$ inclusion pathology within ependymal cells (Fig. 7c).

\section{Discussion}

In this study we showed that recombinant $\alpha S$ prepared from $E$. coli can readily contain bacterial endotoxin/ LPS, which most likely occurs due to the complex electrostatic, hydrophobic, and multimeric structure properties of both $\alpha \mathrm{S}$ and LPS [34, 38, 39, 42]. The identification of LPS contamination in these protein preparations is an important finding since recombinant $\alpha \mathrm{S}$ has been injected into $\alpha \mathrm{S}$ Tg mice, in the form of fibrillar seeds, in order to induce pathology [13, 15-18]. Since LPS is a potent inflammagen, and chronic neuroinflammation is believed to play a substantial role in the development and/or progression of a number of neurodegenerative diseases, including $\operatorname{PD}[6,28,29$, $43,44]$, it stands to reason that its presence would be a significant confound. Indeed it has been published that a single injection of LPS in the brain or peripherally is sufficient, in M83 $\alpha \mathrm{S}$ Tg mice, to induce $\alpha \mathrm{S}$ inclusion pathology [19, 20]. To assess for the involvement of the contaminating LPS in the induction of $\alpha \mathrm{S}$ pathology in these mice, we developed a purification protocol that eliminates almost all of the LPS contaminants (>99.5\%), by exploiting the presence of a region of positive charge that is present in $\alpha \mathrm{S}$, but not in LPS. Stereotaxic hippocampal injections in M83 $\alpha \mathrm{S}$ Tg mice, using fibrils prepared from $\alpha \mathrm{S}$ with or without the additional purification (cation exchanged $\alpha S$ and $\alpha S$, respectively), induced similar amounts and distributions of $\alpha \mathrm{S}$ inclusion pathology except in the cortex, where we observed fewer $\alpha \mathrm{S}$ inclusions in the $\alpha \mathrm{S}$ injected mice. Moreover, we were unable to reproduce the results published by Gao and colleagues [19, 20]; we observed no $\alpha S$ inclusion pathology in homozygous M83 $\alpha \mathrm{S}$ Tg mice injected with purified LPS. However, there were major differences between these studies. First, we injected into the hippocampus whereas Gao et al. injected LPS into the substantia nigra. The dopaminergic cells of the substantia nigra are particularly vulnerable to inflammatory/oxidative stress that can be induced by treatment with LPS, and so the overexpressed $\alpha \mathrm{S}$ may be induced to aggregate due to additional adverse cellular mechanisms. 


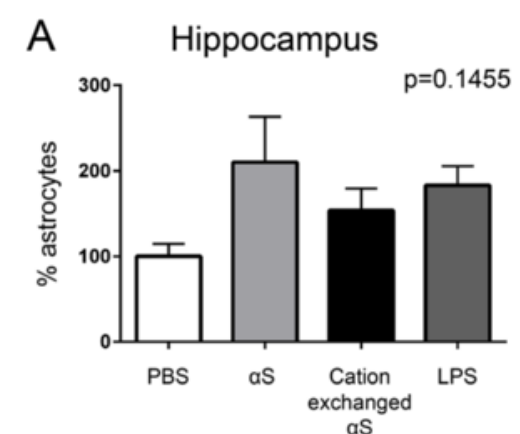

B
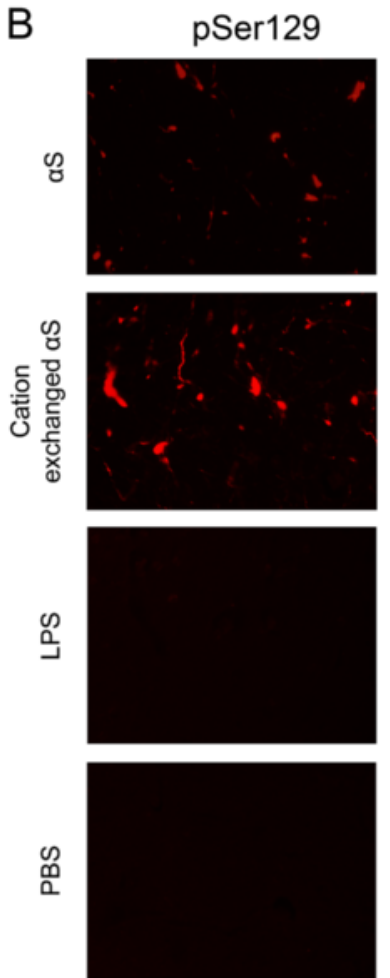

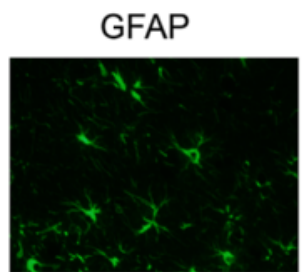

Entorhinal cortex

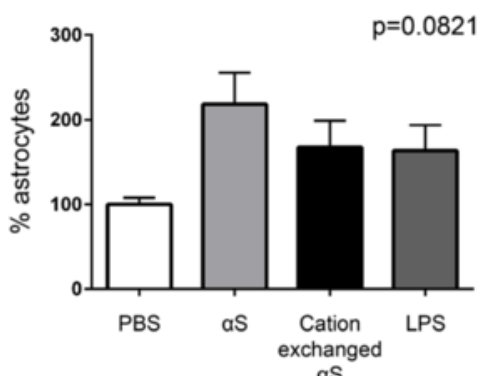

aS
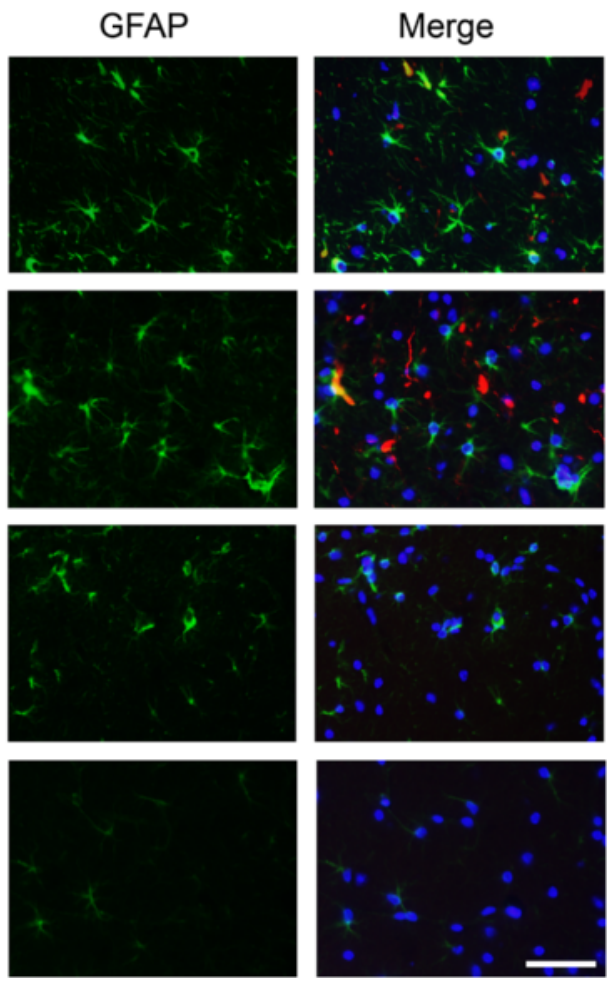

Fig. 5 Astrogliosis and aS inclusions within astrocytes, in M83 aS Tg mice injected with aS fibrils. a Percentage of GFAP-positive astrocytes per field area in the hippocampus (left) and entorhinal cortex (right) of M83 aS Tg mice stereotaxically injected with aS or cation exchanged aS fibrils or LPS in the hippocampus, versus PBS injected mice. P-values were determined by one-way ANOVA analyses. $\mathbf{b}$ Representative images of the hippocampus, showing double immunofluorescent staining with pSer129/81A (aS phosphorylated at Ser129) and GFAP. Individual images were overlaid (Merge) to show colocalization. Scale bar $=50 \mu \mathrm{m}$

Second, the age at which the injections were carried out was different between the two studies. Our mice were injected at 2 months of age, an age which is much earlier than when naïve mice develop pathology or motor symptoms. Gao et al. injected their mice at 7 or 12 months of age, for intraperitoneal and brain injection respectively, which is around the age at which these mice typically develop pathology. They reported that the mice did not present with an overt neurological phenotype at the time of injection however, the mice could already have $\alpha \mathrm{S}$ pathology within their brains or at least would be more prone to developing $\alpha \mathrm{S}$ pathology due to a neurological insult.
These factors could provide a possible explanation for the differences in results observed in the two studies. The LPS used was derived from the same strain of $E$. coli ( $E$. coli 0111:B4), and we injected twice the amount that Gao et al. injected (10ug versus $5 \mathrm{ug}$ ), so the amount and type of LPS is most likely not responsible for the differences seen.

As LPS is known to invoke an inflammatory response, we looked for evidence of neuroinflammation in the mice. We saw the greatest number of astrocytes within the hippocampus and entorhinal cortex of $\alpha \mathrm{S}$ injected mice, with cation exchanged $\alpha S$ and LPS injected mice also having elevated numbers of astrocytes compared to 


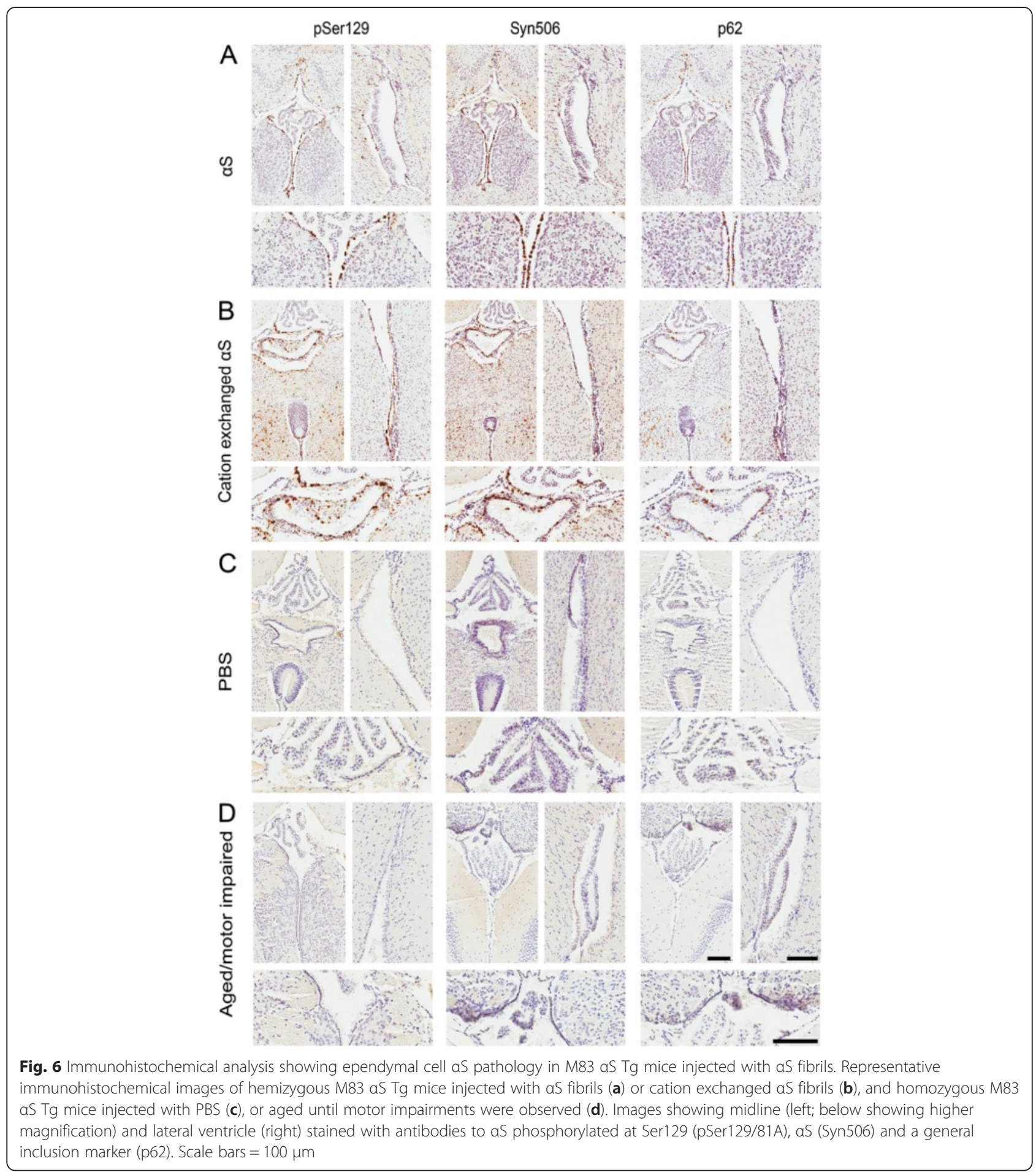

PBS injected mice. However, none of these reached statistical significance. This slight increase in astrogliosis provides a potential explanation to the reduced spread of $\alpha \mathrm{S}$ pathology into the cortex of $\alpha \mathrm{S}$ injected mice. The presence of LPS within the injected sample may be inducing an acute inflammatory response which could result in the removal of some of the $\alpha \mathrm{S}$ seeds. This would lead to the reduction of spread of pathology, with the number of astrocytes returning to near-normal within the 3 months before the mice were sacrificed. Nevertheless, $\alpha \mathrm{S}$ inclusions were present within astrocytes in both $\alpha \mathrm{S}$ and cation exchanged $\alpha \mathrm{S}$ fibril injected mice.

Serendipitously, we observed the presence of $\alpha \mathrm{S}$ inclusions within ependymal cells in the $\alpha S$ (both $\alpha S$ and 

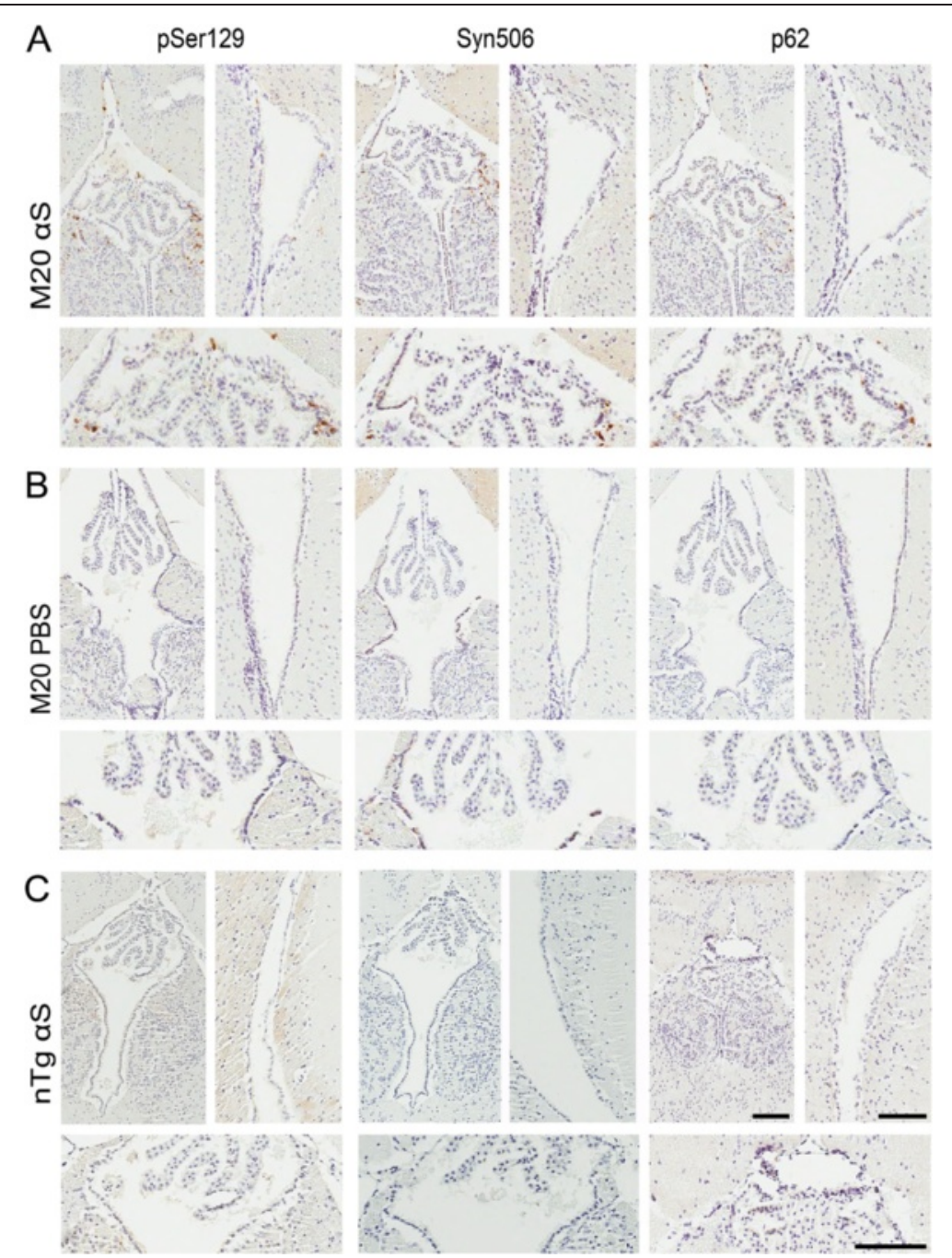

Fig. 7 Immunohistochemical analysis showing ependymal cell aS pathology in M20 aS Tg mice injected with aS fibrils. Representative immunohistochemical images of hemizygous M20 aS Tg mice injected with aS fibrils (a) or PBS (b) and nTg mice injected with aS fibrils (c). Images showing midline (left; below is a higher magnification) and lateral ventricle (right) stained with antibodies to aS phosphorylated at Ser129 (pSer129/81A), aS (Syn506) and a general inclusion marker (p62). Scale bars $=100 \mu \mathrm{m}$

cation exchanged $\alpha S$ ), but not in LPS or PBS injected M83 $\alpha \mathrm{S}$ Tg mice. Furthermore, this ependymal $\alpha \mathrm{S}$ inclusion pathology was not present in aged, motor impaired M83 $\alpha$ S Tg mice. Subsequent examination of M20 $\alpha \mathrm{S}$ Tg mice injected with $\alpha \mathrm{S}$ fibrils revealed a similar but reduced amount of $\alpha \mathrm{S}$ pathology within the ependymal cells, and non-Tg mice injected with $\alpha \mathrm{S}$ fibrils did not develop ependymal cell $\alpha \mathrm{S}$ pathology. This suggests that ependymal $\alpha \mathrm{S}$ inclusion pathology is specific to $\alpha \mathrm{S}$ fibril injected $\alpha \mathrm{S} \operatorname{Tg}$ mice. Pathological studies of human $\alpha-$ synucleinopathies have described $\alpha S$ inclusions within astrocytes, oligodendrocytes, in the sub-ependymal area and between ependymal cells $[45,46]$.

The presence of $\alpha \mathrm{S}$ inclusion pathology in ependymal cells provides a new level of complexity in interpreting the mechanism(s) involved in the spread of $\alpha S$ pathology, as it might provide additional explanations for the potent progression of this phenomenon in these mouse models. As ependymal cells line the ventricular system of the central nervous system, the uptake and release of $\alpha \mathrm{S}$ aggregates from these cells into the cerebrospinal fluid would provide more widespread access to the brain and spinal cord, which could explain the efficient spread of $\alpha \mathrm{S}$ inclusion pathology throughout the neuroaxis of these mice. Although some cell culture studies have provided decent evidence that $\alpha S$ conformational templating can occur under certain cellular conditions [47-49], the mechanisms involved in whole animal studies are more challenging to delineate due to the complex interactions of the biological mechanisms that can be 
involved [50, 51]. Given our new findings, additional studies are required to determine the relative contributions of various physiological and cellular mechanisms to the induction and spread of $\alpha S$ inclusion pathology in the $\alpha \mathrm{S}$ fibril injected $\alpha \mathrm{S}$ Tg mouse models.

\section{Conclusions}

We have shown here that the presence of LPS in bacterially produced $\alpha S$ is not a major factor involved in the induction of $\alpha \mathrm{S}$ inclusion pathology resulting from the cerebral injection of preformed recombinant $\alpha S$ amyloid seeds in M83 $\alpha \mathrm{S}$ Tg mice. However, the presence of LPS levels should be considered when using bacterially expressed $\alpha \mathrm{S}$ in biological studies. Furthermore we demonstrated the presence of $\alpha \mathrm{S}$ inclusions within ependymal cells of $\alpha \mathrm{S} \mathrm{Tg}$ mice injected in the cerebrum with $\alpha S$ fibrils to induce the spread of $\alpha S$ inclusion pathology, which puts forth a novel mechanism that could contribute to this process in these animal models.

\section{Methods}

\section{Antibodies}

pSer129, also known as clone $81 \mathrm{~A}$, is a mouse monoclonal antibody that reacts with $\alpha \mathrm{S}$ phosphorylated at Ser129 [52]. Syn506 is a conformational anti- $\alpha \mathrm{S}$ mouse monoclonal antibody that preferentially detects $\alpha S$ in pathological inclusions [53, 54]. SNL4 is a rabbit polyclonal antibody that recognizes $\mathrm{N}$-terminal residues $2-12$ in $\alpha \mathrm{S}$ [55]. Antip62 is a rabbit polyclonal antibody that is a general protein inclusion marker (SQSTM1; ProteinTech). Rabbit polyclonal anti-GFAP detects glial fibrillary acidic protein, and is a marker of astrocytes (Dako).

\section{Recombinant aS expression and purification}

The bacterial expression plasmid; pRK172, encoding full length human $\alpha \mathrm{S}$ was previously described [56]. Recombinant $\alpha S$ was expressed in BL21(DE3)/RIL E. coli (Agilent Technologies) and purified by size exclusion chromatography and subsequent Mono-Q ion exchange chromatography as previously described $[56,57]$. To further purify $\alpha \mathrm{S}$ and remove LPS contamination, we tested a number of different absorption resins including hydroxyapatite (BioRad), hydrophobic resins, lipid removing agent (LRA; Sigma) and Mono-S ion exchange (Bio-Rad), using buffers with a range of $\mathrm{pH}$ values. In the most successful approach, samples were purified by High S Support cation exchange chromatography (Bio-Rad). The protein was exchanged with $20 \mathrm{mM}$ PIPES, pH4.2, bound to the High S resin, extensively washed with $20 \mathrm{mM}$ PIPES, pH4.2 and eluted with $20 \mathrm{mM}$ PIPES, pH4.2, $1 \mathrm{M} \mathrm{NaCl}$. The purified protein was then exchanged with PBS. Protein concentrations were quantified using the bicinchoninic acid (BCA) assay (Thermo Scientific), using bovine serum albumin as a standard (Pierce Biotechnology).

\section{Detection and quantification of endotoxin contamination}

To assay for the presence of lipopolysaccharide (LPS) in the $\alpha \mathrm{S}$ protein preparations, two methods were employed: 1) the HEK-Blue-hTLR4 cell culture system and QUANTIBlue media (InvivoGen) according to the manufacturer's protocol, and 2) the Pierce LAL Chromogenic Endotoxin Quantitation Kit (Thermo Scientific) according to the manufacturer's protocol, using the included endotoxin standard for both assays. Standards and protein samples were prepared by dilution in endotoxin free water. Absorbance values were determined by plate reader, and for some samples were above the range of detection.

\section{Fibril formation of recombinant aS proteins}

Fibrils were formed by incubating the $\alpha \mathrm{S}$ proteins at $5 \mathrm{mg} / \mathrm{ml}$ in sterile PBS at $37^{\circ} \mathrm{C}$ with constant shaking at $1050 \mathrm{rpm}$ (Thermomixer R, Eppendorf) for $48 \mathrm{~h}$. Fibril formation was monitored by (trans,trans)-1-bromo-2,5bis-(4-hydroxy)styrylbenzene (K114) fluorometry as previously described [58]. Fibrils were prepared for injection by diluting the samples in sterile PBS followed by mild sonication in a water bath for $2 \mathrm{~h}$.

\section{Mouse husbandry and stereotaxic brain injections}

All procedures were performed according to the NIH Guide for the Care and Use of Experimental Animals and were approved by the University of Florida Institutional Animal Care and Use Committee. Tg mice expressing wild-type human $\alpha \mathrm{S}$ (M20 line) or human $\alpha \mathrm{S}$ containing the A53T mutation (M83 line), were previously described [40]. Two month old M83 $\alpha \mathrm{S}$ Tg mice were bilaterally stereotaxically injected in the hippocampus (coordinates from Bregma: $\mathrm{A} / \mathrm{P}-1.7, \mathrm{~L} \pm 1.6$, $\mathrm{D} / \mathrm{V}-2.0)$ with $2.5 \mu \mathrm{l} \alpha \mathrm{S}$ fibrils $(1.6 \mathrm{mg} / \mathrm{mL})$ or $\alpha \mathrm{S}$ fibrils purified of LPS $(1.6 \mathrm{mg} / \mathrm{ml})$, or $2.0 \mu \mathrm{l} \mathrm{LPS}(5 \mathrm{mg} /$ ml; E. coli 0111:B4; Sigma) or sterile PBS (summarized in Table 1), at a rate of $0.2 \mu \mathrm{l} /$ minute. A cohort of two month old M20 Tg mice and non-Tg mice was also stereotaxically injected in the hippocampus with $2.0 \mu \mathrm{l}$ $\alpha$ S fibrils $(2.0 \mathrm{mg} / \mathrm{mL})$ or sterile PBS (M20 $\alpha \mathrm{S}$ Tg mice only). Mice were sacrificed by $\mathrm{CO}_{2}$ euthanization followed by cardiac perfusion with PBS/heparin. The brain and spinal cord were harvested and fixed in $70 \%$ ethanol/150 $\mathrm{mM} \mathrm{NaCl}$. The tissue was then dehydrated, paraffinized as previously described [59] and cut into $7 \mu \mathrm{m}$ sections.

\section{Immunohistochemistry}

Tissue sections were deparaffinized in xylene and rehydrated in a descending ethanol series (100\%, $90 \%, 70 \%)$. Antigen retrieval was performed by incubation in a 
Table 1 Summary of aS Tg mice stereotaxically injected in the hippocampus

\begin{tabular}{|c|c|c|c|c|}
\hline Mouse line & Number of mice & Months post-injection at death & Inoculate & Volume $(\mu \mathrm{l})$ \\
\hline$\overline{M 83^{+/-}}$ & 4 & 3 & $\mathrm{aS}(1.6 \mathrm{mg} / \mathrm{ml})$ & 2.5 \\
\hline $\mathrm{M} 83^{+/-}$ & 4 & 3 & Cation-exchanged as (1.6 mg/ml) & 2.5 \\
\hline $\mathrm{M} 83^{+/+}$ & 4 & 2 & LPS (5 mg/ml) & 2 \\
\hline $\mathrm{M} 83^{+/+}$ & 4 & 2 & PBS & 2 \\
\hline $\mathrm{M} 2 \mathrm{O}^{+/-}$ & 4 & 4 & aS (2 mg/ml) & 2 \\
\hline $\mathrm{M} 2 \mathrm{O}^{+/-}$ & 2 & 2 & PBS & 2 \\
\hline $\mathrm{M} 2 \mathrm{O}^{+/-}$ & 5 & 4 & PBS & 2 \\
\hline $\mathrm{M} 2 \mathrm{O}^{+/-}$ & 4 & 7 & PBS & 2 \\
\hline$n T g$ & 4 & 4 & as $(2 \mathrm{mg} / \mathrm{ml})$ & 2 \\
\hline
\end{tabular}

${ }_{+/-}^{+}$hemizygous, ${ }^{+/+}=$homozygous

steam bath for $30 \mathrm{~min}$. Endogenous peroxidase activity was quenched, and samples were blocked with $2 \%$ fetal bovine serum (FBS)/0.1 M Tris pH7.6. Primary antibodies were diluted in blocking solution and applied to samples for overnight incubation at $4{ }^{\circ} \mathrm{C}$. Anti-rabbit or anti-mouse biotinylated antibodies were diluted in blocking solution and applied to sections for an hour at room temperature. Next, the avidin-biotin complex (ABC) Vectastain system (Vector Laboratories) was employed and immunocomplexes were visualized with the chromogen 3,3'-diaminobenzidine (DAB). Sections were counterstained with hematoxylin followed by dehydration in an ascending series of ethanols (70\%, $90 \%$, $100 \%)$ and xylene. Sections were coverslipped using cytoseal and dried before scanning using an Aperio ScanScope CS (40x magnification; Aperio Technologies Inc.). Representative images (for figures) and images showing the hippocampus or the entorhinal cortex (for astrocyte counting) were taken using the ImageScope TM software (Aperio Technologies Inc.).

\section{Double immunofluorescence}

Tissue sections were deparaffinized and rehydrated, and antigen retrieval was performed as described in the immunohistochemistry methods. Sections were blocked with $5 \%$ dry milk/0.1 M Tris pH7.6. Primary antibodies were diluted in blocking solution and applied to sections for overnight incubation at $4{ }^{\circ} \mathrm{C}$. Sections were washed with $0.1 \mathrm{M}$ Tris pH7.6 and secondary antibodies conjugated to Alexa Fluor 488 or 594 fluorophores (Life Technologies) were diluted in blocking solution and applied to sections for $2 \mathrm{~h}$ at room temperature in the dark. Sections were then treated with sudan black to block lipofuscin autofluorescence. Nuclei were stained with 4,6-diamidino-2phenylindole (DAPI; Pierce) and sections were mounted using Fluoromount-G (SouthernBiotech). Pictures were obtained using an Olympus BX51 fluorescent microscope and images were overlaid using Photoshop CS6 software.

\section{Quantification of staining, cell counts and statistical analyses}

Scanned images of Syn506 stained sections were loaded into ImageScope TM software. The hippocampal areas were outlined and analyzed for the abundance of DAB positive pixels. The burden was calculated by dividing the number of positive pixels by the area. Images obtained from the CA2/3 of the hippocampus and entorhinal cortex of GFAP-DAB stained sections were taken at 10x using ImageScope TM software. The images were randomized and coded, and the numbers of GFAP positive cells were counted by a single user, blinded to the experimental conditions. Two-tailed t-tests and one-way analysis of variance (ANOVA) with post-hoc Dunnett's multiple comparison tests were performed in GraphPad Prism v5.03 software.

\section{Activation of an inflammatory response in primary microglia by purified LPS}

The cortices from $\mathrm{B} 6 / \mathrm{C} 3 \mathrm{H}$ P0-P2 mice were isolated as previously described [60]. The mixed glial cultures were maintained in DMEM/10 \% FBS with 100 units/ml penicillin and $100 \mu \mathrm{g} / \mathrm{ml}$ streptomycin. After 10-14 days of incubation, flasks were shaken at $150 \mathrm{rpm}$ for $30 \mathrm{~min}$ at $37{ }^{\circ} \mathrm{C}$ to dislodge microglia from the astrocyte layer. The microglial cells were then re-plated into 6 well culture dishes in DMEM/10 \% FBS with 100 units $/ \mathrm{ml}$ penicillin and $100 \mu \mathrm{g} / \mathrm{ml}$ streptomycin. All cells were maintained at $37{ }^{\circ} \mathrm{C}$ in a humidified incubator with $5 \% \mathrm{CO} 2$. When the primary microglial cultures reached $\sim 60 \%$ confluency, the media was removed from the wells and was replaced with $2 \mathrm{ml}$ of media containing $50 \mathrm{ng} / \mathrm{ml} \mathrm{LPS}$. Control wells received the same treatment, without the addition of LPS ( $n=3$ /group). The cultures were returned to the incubator for 1,6 or $12 \mathrm{~h}$. Following incubation, images of the cultures were obtained using an EVOS FL cell imaging system (AMG). Then, the media was removed, mixed with protease inhibitors and aliquoted. The amount of IL- 6 within the 
media (diluted 1:50) was determined using a BD OptEIA mouse IL-6 ELISA kit according to the manufacturer's protocol (BD biosciences).

\section{Additional file}

Additional file 1: Figure S1. Assessment of endotoxin activity within purified LPS. (A) Comparison of the activity of purified LPS (E. coli 0111:B4), that was used for cerebral injection, to standard endotoxin using the Pierce LAL assay. White bars represent the endotoxin standard and black bars represent test samples. (B) Images showing the morphology of primary microglia in culture following 6 and $12 \mathrm{~h}$ of treatment with $50 \mathrm{ng} /$ $\mathrm{ml}$ purified LPS or nothing (control). Scale bar $=200 \mu \mathrm{m}$. (C) Detection of IL-6 within the media (diluted 1:50, $100 \mu$ l) taken from primary microglia cultures after 1 or $6 \mathrm{~h}$ of treatment with $50 \mathrm{ng} / \mathrm{ml}$ purified LPS or nothing (control). White bars represent IL-6 standard. Black bars represent test samples. Error bars represent the standard error of the mean. $A U=$ absorbance units. (TIFF $4630 \mathrm{~kb}$ )

\section{Abbreviations}

ABC: Avidin-biotin complex; ANOVA: Analysis of variance; aS: a-synuclein; BCA: Bicinchoninic acid; CNS: Central nervous system; $\mathrm{CO}_{2}$ : Carbon dioxide; DAPI: 4',6-diamidino-2-phenylindole; DAB: 3,3'-diaminobenzidine; DLB: Dementia with Lewy bodies; E. coli: Escherichia coli; EU: Endotoxin units; ELISA: Enzyme-linked immunosorbent assay; FBS: Fetal bovine serum; GFAP: Glial fibrillary acidic protein; HEK: Human embryonic kidney; IL6: Interleukin-6; K1 14: (trans,trans)-1-bromo-2,5-bis-(4-hydroxy)styrylbenzene; LPS: Lipopolysaccharide; NAC: Non-amyloid component; PBS: Phosphate buffered saline; PD: Parkinson's disease; Tg: Transgenic; TLR4: Toll-like receptor 4 .

\section{Competing interests}

The authors declare that they have no competing interests.

\section{Authors' contributions}

NJR performed endotoxin quantitation, immunohistochemistry, immunofluorescent staining, ELISAs, statistical analyses and drafted the manuscript. ANS performed animal surgeries. MB maintained the animal colony, performed humane perfusion on the animals, and harvested and processed tissue. CCD prepared primary microglial cultures and assisted in the analysis of these cultures. JKH counted astrocytes from stained mouse brain sections. TBL participated in the design of the study. TEG participated in the design of the study and critically revised the manuscript. BIG participated in the design of the study, performed protein expression and purification, including endotoxin purification, and critically revised the manuscript. All authors read and approved the final manuscript.

\section{Acknowledgements}

This work was supported by grants from the NINDS (NS089622) and the National Parkinson Foundation.

\section{Received: 26 May 2015 Accepted: 22 July 2015}

\section{Published online: 30 July 2015}

\section{References}

1. Spillantini MG, Schmidt ML, Lee VM, Trojanowski JQ, Jakes R, Goedert M. Alpha-synuclein in Lewy bodies. Nature. 1997;388(6645):839-40.

2. Cookson MR. The biochemistry of Parkinson's disease. Annu Rev Biochem. 2005;74:29-52

3. Hunot $\mathrm{S}$, Hirsch EC. Neuroinflammatory processes in Parkinson's disease. Ann Neurol. 2003:53 Suppl 3:S49-58. discussion S58-60.

4. Whitton PS. Inflammation as a causative factor in the aetiology of Parkinson's disease. Br J Pharmacol. 2007;150(8):963-76.

5. Goedert M. Filamentous nerve cell inclusions in neurodegenerative diseases: tauopathies and alpha-synucleinopathies. Philos Trans R Soc Lond B Biol Sci. 1999;354(1386):1101-18.

6. Goedert M. Alpha-synuclein and neurodegenerative diseases. Nat Rev Neurosci. 2001;2(7):492-501.
7. Spillantini MG, Goedert M. The alpha-synucleinopathies: Parkinson's disease, dementia with Lewy bodies, and multiple system atrophy. Ann N Y Acad Sci. 2000;920:16-27.

8. Braak H, Del Tredici K, Rüb U, de Vos RAl, Jansen Steur ENH, Braak E. Staging of brain pathology related to sporadic Parkinson's disease. Neurobiol Aging. 2003;24(2):197-211.

9. Braak H, Ghebremedhin E, Rüb U, Bratzke H, Del Tredici K. Stages in the development of Parkinson's disease-related pathology. Cell Tissue Res. 2004;318(1):121-34.

10. Kordower JH, Chu Y, Hauser RA, Freeman TB, Olanow CW. Lewy body-like pathology in long-term embryonic nigral transplants in Parkinson's disease. Nat Med. 2008;14(5):504-6.

11. Li J-Y, Englund E, Holton JL, Soulet D, Hagell P, Lees AJ, et al. Lewy bodies in grafted neurons in subjects with Parkinson's disease suggest host-to-graft disease propagation. Nat Med. 2008;14(5):501-3.

12. Li J-Y, Englund E, Widner H, Rehncrona S, Björklund A, Lindvall O, et al. Characterization of Lewy body pathology in 12- and 16-year-old intrastriatal mesencephalic grafts surviving in a patient with Parkinson's disease. Mov Disord Off J Mov Disord Soc. 2010;25(8):1091-6.

13. Luk KC, Kehm VM, Zhang B, O'Brien P, Trojanowski JQ, Lee VMY. Intracerebral inoculation of pathological a-synuclein initiates a rapidly progressive neurodegenerative a-synucleinopathy in mice. J Exp Med. 2012;209(5):975-86.

14. Luk KC, Kehm V, Carroll J, Zhang B, O'Brien P, Trojanowski JQ, et al. Pathological a-synuclein transmission initiates Parkinson-like neurodegeneration in nontransgenic mice. Science. 2012;338(6109):949-53.

15. Sacino AN, Brooks M, McGarvey NH, McKinney AB, Thomas MA, Levites $Y$, et al. Induction of CNS a-synuclein pathology by fibrillar and non-amyloidogenic recombinant a-synuclein. Acta Neuropathol Commun. 2013;1(1):38.

16. Sacino AN, Brooks M, Thomas MA, McKinney AB, McGarvey NH, Rutherford NJ, et al. Amyloidogenic a-synuclein seeds do not invariably induce rapid, widespread pathology in mice. Acta Neuropathol (Berl). 2014;127(5):645-65.

17. Sacino AN, Brooks M, Thomas MA, McKinney AB, Lee S, Regenhardt RW, et al. Intramuscular injection of a-synuclein induces CNS a-synuclein pathology and a rapid-onset motor phenotype in transgenic mice. Proc Natl Acad Sci U S A. 2014;111(29):10732-7.

18. Masuda-Suzukake M, Nonaka T, Hosokawa M, Oikawa T, Arai T, Akiyama $\mathrm{H}$, et al. Prion-like spreading of pathological a-synuclein in brain. Brain J Neurol. 2013;136(Pt 4):1128-38.

19. Gao H-M, Kotzbauer PT, Uryu K, Leight S, Trojanowski JQ, Lee VM-Y. Neuroinflammation and oxidation/nitration of alpha-synuclein linked to dopaminergic neurodegeneration. J Neurosci Off J Soc Neurosci. 2008;28(30):7687-98.

20. Gao H-M, Zhang F, Zhou H, Kam W, Wilson B, Hong J-S. Neuroinflammation and a-synuclein dysfunction potentiate each other, driving chronic progression of neurodegeneration in a mouse model of Parkinson's disease. Environ Health Perspect. 2011;119(6):807-14.

21. Park BS, Lee J-O. Recognition of lipopolysaccharide pattern by TLR4 complexes. Exp Mol Med. 2013;45:e66.

22. Beutler B. TIr4: central component of the sole mammalian LPS sensor. Curr Opin Immunol. 2000;12(1):20-6.

23. Klegeris A, Giasson Bl, Zhang H, Maguire J, Pelech S, McGeer PL Alpha-synuclein and its disease-causing mutants induce ICAM-1 and IL-6 in human astrocytes and astrocytoma cells. FASEB J Off Publ Fed Am Soc Exp Biol. 2006;20(12):2000-8.

24. Austin SA, Floden AM, Murphy EJ, Combs CK. Alpha-synuclein expression modulates microglial activation phenotype. J Neurosci Off J Soc Neurosci. 2006;26(41):10558-63.

25. Klegeris A, Pelech S, Giasson Bl, Maguire J, Zhang H, McGeer EG, et al. Alpha-synuclein activates stress signaling protein kinases in THP-1 cells and microglia. Neurobiol Aging. 2008;29(5):739-52.

26. Su X, Maguire-Zeiss KA, Giuliano R, Prifti L, Venkatesh K, Federoff HJ. Synuclein activates microglia in a model of Parkinson's disease. Neurobiol Aging. 2008;29(11):1690-701.

27. Rojanathammanee L, Murphy EJ, Combs CK. Expression of mutant alpha-synuclein modulates microglial phenotype in vitro. J Neuroinflammation. 2011;8:44.

28. Kim YS, Joh TH. Microglia, major player in the brain inflammation: their roles in the pathogenesis of Parkinson's disease. Exp Mol Med. 2006;38(4):333-47. 
29. Tansey MG, Goldberg MS. Neuroinflammation in Parkinson's disease: its role in neuronal death and implications for therapeutic intervention. Neurobiol Dis. 2010;37(3):510-8

30. McGeer PL, Itagaki S, Boyes BE, McGeer EG. Reactive microglia are positive for HLA-DR in the substantia nigra of Parkinson's and Alzheimer's disease brains. Neurology. 1988;38(8):1285-91.

31. Nagatsu T, Mogi M, Ichinose $H$, Togari A. Changes in cytokines and neurotrophins in Parkinson's disease. J Neural Transm Suppl. 2000;60:277-90.

32. Hirsch EC, Breidert T, Rousselet E, Hunot S, Hartmann A, Michel PP. The role of glial reaction and inflammation in Parkinson's disease. Ann N Y Acad Sci. 2003;991:214-28.

33. Davidson WS, Jonas A, Clayton DF, George JM. Stabilization of alpha-synuclein secondary structure upon binding to synthetic membranes. J Biol Chem. 1998;273(16):9443-9.

34. Hirayama C, Sakata M. Chromatographic removal of endotoxin from protein solutions by polymer particles. J Chromatogr B Analyt Technol Biomed Life Sci. 2002:781(1-2):419-32.

35. Magalhães PO, Lopes AM, Mazzola PG, Rangel-Yagui C, Penna TCV, Pessoa A. Methods of endotoxin removal from biological preparations: a review. J Pharm Pharm Sci Publ Can Soc Pharm Sc Société Can Sci Pharm. 2007;10(3):388-404.

36. Wilson M, Blum R, Dandona P, Mousa S. Effects in humans of intravenously administered endotoxin on soluble cell-adhesion molecule and inflammatory markers: a model of human diseases. Clin Exp Pharmacol Physiol. 2001;28(5-6):376-80.

37. Malyala $P$, Singh M. Endotoxin limits in formulations for preclinical research. J Pharm Sci. 2008;97(6):2041-4

38. Shands JW, Graham JA, Nath K. The morphologic structure of isolated bacterial lipopolysaccharide. J Mol Biol. 1967;25(1):15-21.

39. Ribi E, Anacker RL, Brown R, Haskins WT, Malmgren B, Milner KC, et al. Reaction of endotoxin and surfactants. I. Physical and biological properties of endotoxin treated with sodium deoxycholate. J Bacteriol. 1966;92(5):1493-509

40. Giasson BI, Duda JE, Quinn SM, Zhang B, Trojanowski JQ, Lee VM-Y. Neuronal alpha-synucleinopathy with severe movement disorder in mice expressing A53T human alpha-synuclein. Neuron. 2002;34(4):521-33.

41. Sacino AN, Brooks M, McKinney AB, Thomas MA, Shaw G, Golde TE, et al. Brain injection of a-synuclein induces multiple proteinopathies, gliosis, and a neuronal injury marker. J Neurosci Off J Soc Neurosci. 2014;34(37):12368-78

42. Plotegher N, Greggio E, Bisaglia M, Bubacco L. Biophysical groundwork as a hinge to unravel the biology of a-synuclein aggregation and toxicity. Q Rev Biophys. 2014;47(1):1-48.

43. Ling Z, Zhu Y, Tong Wai C, Snyder JA, Lipton JW, Carvey PM. Progressive dopamine neuron loss following supra-nigral lipopolysaccharide (LPS) infusion into rats exposed to LPS prenatally. Exp Neurol. 2006;199(2):499-512.

44. Qin L, Wu X, Block ML, Liu Y, Breese GR, Hong J-S, et al. Systemic LPS causes chronic neuroinflammation and progressive neurodegeneration. Glia. 2007;55(5):453-62.

45. Wakabayashi K, Hayashi S, Yoshimoto M, Kudo H, Takahashi H. NACP/ alpha-synuclein-positive filamentous inclusions in astrocytes and oligodendrocytes of Parkinson's disease brains. Acta Neuropathol (Berl). 2000;99(1):14-20.

46. Kovacs GG, Breydo L, Green R, Kis V, Puska G, Lőrincz P, et al. Intracellular processing of disease-associated a-synuclein in the human brain suggests prion-like cell-to-cell spread. Neurobiol Dis. 2014;69:76-92.

47. Sacino AN, Thomas MA, Ceballos-Diaz C, Cruz PE, Rosario AM, Lewis J, et al Conformational templating of a-synuclein aggregates in neuronal-glial cultures. Mol Neurodegener. 2013;8:17.

48. Luk KC, Song C, O'Brien P, Stieber A, Branch JR, Brunden KR, et al. Exogenous alpha-synuclein fibrils seed the formation of Lewy body-like intracellular inclusions in cultured cells. Proc Natl Acad Sci U S A. 2009;106(47):20051-6.

49. Waxman EA, Giasson BI. A novel, high-efficiency cellular model of fibrillar alpha-synuclein inclusions and the examination of mutations that inhibit amyloid formation. J Neurochem. 2010;113(2):374-88.

50. Golde TE, Borchelt DR, Giasson BI, Lewis J. Thinking laterally about neurodegenerative proteinopathies. J Clin Invest. 2013;123(5):1847-55.
51. Brundin P, Li J-Y, Holton JL, Lindvall O, Revesz T. Research in motion: the enigma of Parkinson's disease pathology spread. Nat Rev Neurosci. 2008;9(10):741-5.

52. Waxman EA, Giasson BI. Specificity and regulation of casein kinase-mediated phosphorylation of alpha-synuclein. J Neuropathol Exp Neurol. 2008:67(5):402-16.

53. Waxman EA, Duda JE, Giasson BI. Characterization of antibodies that selectively detect alpha-synuclein in pathological inclusions. Acta Neuropathol (Berl). 2008;116(1):37-46.

54. Duda JE, Giasson BI, Mabon ME, Lee VM-Y, Trojanowski JQ. Novel antibodies to synuclein show abundant striatal pathology in Lewy body diseases. Ann Neurol. 2002;52(2):205-10.

55. Giasson Bl, Jakes R, Goedert M, Duda JE, Leight S, Trojanowski JQ, et al. A panel of epitope-specific antibodies detects protein domains distributed throughout human alpha-synuclein in Lewy bodies of Parkinson's disease. J Neurosci Res. 2000;59(4):528-33.

56. Giasson Bl, Murray IV, Trojanowski JQ, Lee VM. A hydrophobic stretch of 12 amino acid residues in the middle of alpha-synuclein is essential for filament assembly. J Biol Chem. 2001;276(4):2380-6.

57. Greenbaum EA, Graves CL, Mishizen-Eberz AJ, Lupoli MA, Lynch DR, Englander SW, et al. The E46K mutation in alpha-synuclein increases amyloid fibril formation. J Biol Chem. 2005;280(9):7800-7.

58. Crystal AS, Giasson BI, Crowe A, Kung M-P, Zhuang Z-P, Trojanowski JQ, et al. A comparison of amyloid fibrillogenesis using the novel fluorescent compound K114. J Neurochem. 2003;86(6):1359-68.

59. Duda JE, Giasson Bl, Gur TL, Montine TJ, Robertson D, Biaggioni I, et al, Immunohistochemical and biochemical studies demonstrate a distinct profile of alpha-synuclein permutations in multiple system atrophy. J Neuropathol Exp Neurol. 2000;59(9):830-41.

60. Chakrabarty P, Jansen-West K, Beccard A, Ceballos-Diaz C, Levites $Y$, Verbeeck $C$, et al. Massive gliosis induced by interleukin- 6 suppresses Abeta deposition in vivo: evidence against inflammation as a driving force for amyloid deposition. FASEB J. 2010;24(2):548-59.

\section{Submit your next manuscript to BioMed Central and take full advantage of:}

- Convenient online submission

- Thorough peer review

- No space constraints or color figure charges

- Immediate publication on acceptance

- Inclusion in PubMed, CAS, Scopus and Google Scholar

- Research which is freely available for redistribution

Submit your manuscript at www.biomedcentral.com/submit
C Biomed Central 